\title{
Ground Vibration During Gravel Pile Construction
}

Jin-Hung Hwang

Associate Professor, Department of Civil Engineering, National Central University, Chungli, Taiwan

Tung-Yueh Tu

Doctoral Student, Department of Civil Engineering, National Central University, Chungli, Taiwan

Follow this and additional works at: https://jmstt.ntou.edu.tw/journal

Part of the Civil and Environmental Engineering Commons

\section{Recommended Citation}

Hwang, Jin-Hung and Tu, Tung-Yueh (2002) "Ground Vibration During Gravel Pile Construction," Journal of Marine Science and Technology. Vol. 10: Iss. 1, Article 6.

DOI: $10.51400 / 2709-6998.2299$

Available at: https://jmstt.ntou.edu.tw/journal/vol10/iss1/6

This Research Article is brought to you for free and open access by Journal of Marine Science and Technology. It has been accepted for inclusion in Journal of Marine Science and Technology by an authorized editor of Journal of Marine Science and Technology. 


\section{Ground Vibration During Gravel Pile Construction}

\section{Acknowledgements}

This research was sponsored by RSEA Company. The author would like to extend his sincere gratitude to RSEA for the support. 


\title{
GROUND VIBRATION DURING GRAVEL PILE CONSTRUCTION
}

\author{
Jin-Hung Hwang* and Tung-Yueh Tu**
}

Key words: Ground vibration, gravel pile, attenuation, spectral analysis.

\begin{abstract}
This investigation performs a field measurement of ground vibration due to gravel pile construction at a hydraulic-filled reclamation land. The ground vibrations were characterized by wave form, Fourier spectrum and response spectrum. The attenuation relation between both peak ground velocity and acceleration with distance was also derived from the measured data. An empirical method for evaluating the safe construction distance to adjacent building structures was presented based on the attenuation relation and a building vibration criterion. Vibration response spectra were also suggested for use with the spectral analysis method to determine more accurately the safe construction distance.
\end{abstract}

\section{INTRODUCTION}

Ground vibrations due to construction operations become a major concern when influencing surrounding structures. Since the need for environmental protection has increased over recent years, the impact of construction vibrations on the surrounding environment has attracted much attention from the field of geoenvironmental engineering. During the last century, much research was devoted to the ground vibrations induced by various geotechnical constructions. Most research [1-4] focused on ground vibrations due to pile driving. Some research considered construction vibrations due to dynamic compaction $[5,6]$ and sheet-piling operations $[7,8]$. Gravel pile construction is a vibrocompaction method for improving deep, soft ground. In Taiwan, vibro-compaction with a gravel pile was first introduced to improve ground at the Kaoshing LinYuan Industrial Park in the early 1980s. In the 1990s, the construction of Taiwan Plastic Miliao Industrial Park saw much ground improvement work that used the

Paper Received Dec. 20, 2001. Author for Correspondence: J. H. Hwang. *Associate Professor, Department of Civil Engineering, National Central University, Chungli, Taiwan

**Doctoral Student, Department of Civil Engineering, National Central University, Chungli, Taiwan method. The gravel pile is increasingly popular for ground improvement, and so the effect of resulting ground vibrations on the surrounding environment must be thoroughly understood. A review of the literature reveals that little relevant information is available. This study involves the field measurement of ground vibration due to gravel pile construction at a hydraulic-filled reclamation site. This paper summarizes site condition and geology, vibration measurement, data analysis, suggested methods to determine the safe construction distance.

\section{TEST SITE AND GEOLOGICAL CONDITIONS}

The test site is located at one of the industrial plants of Taichung Harbor. Figure 1 shows the layout of



Fig. 1. The layout of the plant and the alignment of velocity sensors in the test site. 
the plant and the line along which the vibration sensors were installed. Figure 2 shows the geological profile and shear wave velocity along the line. The topography of the test site is flat with ground surface elevations between $+7.30 \mathrm{~m}$ and $+7.50 \mathrm{~m}$. The soil consists mainly of a deep-thick layer of gray silty fine sand, occasionally interbedded with a layer of silty clay several tens of centimeters thick. A gravelly soil with a thickness of $60 \mathrm{~cm}-120 \mathrm{~cm}$ was back filled on the ground surface. The shear wave velocity varied between 120 and $300 \mathrm{~m} / \mathrm{sec}$ from the ground surface to a depth of $15 \mathrm{~m}$ below the surface.

\section{CONSTRUCTION OF GRAVEL PILE}

The construction of a gravel pile on the test site used a modified machine with a specially designed bottom feeder. Figure 3 schematically shows the construction sequences. During construction, the vibrator first generates a lateral vibratory force to liquefy the



Fig. 2. The geological profile and shear wave velocity along the line of measurement.



Fig. 3. The construction sequences of gravel pile with a bottom feeder design. saturated sandy soils and then penetrates down to the design depth under its self-weight and external hydraulic pressure or compressed air pressure. When the vibrator is pulled up by around $0.5-1.0 \mathrm{~m}$, the gravel material is poured into a vertical transport pipe using a lifting bucket which raises the gravel on the ground to a hopper mounted on the top of pipe. The gravel then goes through the pipe, and the space between the vibrator and the bottom of the construction hole is filled with gravel. When the space is completely filled, the vibrator squeezes the surrounding ground downward and laterally so as to form a compact gravel pile. The vibrator is pulled up when the vibratory compaction pressure reaches a limiting value or the vibro-compaction time reaches 2 minutes. The gravel pile is completed by repeating the above steps of pulling up the vibrator, feeding the gravel and squeezing the surrounding soil between the design depth to the ground surface.

The vibrator used in this study is a German Keller S20120 vibrator, illustrated in Fig. 4. The operating frequency of the vibrator is $30 \mathrm{~Hz}$. The vibratory amplitude is $17 \mathrm{~mm}$ and the centrifugal force is $206 \mathrm{kN}$. The vibrator is driven by an electric motor at an operating frequency of $60 \mathrm{~Hz}$, a rotation speed of $1775 \mathrm{rpm}$ and a power of $120 \mathrm{~kW}$. The gravel pile is $20 \mathrm{~m}$ long and has a diameter of $100 \mathrm{~cm}$. The pile's center to center spacing is $2.5 \mathrm{~m}$.

\section{VIBRATION MEASUREMENT}

Ground vibration was measured during the construction of a full length gravel pile. Figure 5 presents the profile of the measurement. Six stations were installed along the line of measurement. Every station had two velocity sensors, one of which measures vertical velocity and the other measures radial velocity. The closest station was $5 \mathrm{~m}$ distant from the center of gravel pile and the farthest one was $80 \mathrm{~m}$ from the center of the pile. The measurement was performed as follows.

1. The background vibration was recorded before the machine was turned on.

2 . The background vibration was recorded as the vibrator and rotating rod were started.

3 . The vibration during a construction cycle including feeding, compacting and squeezing, was recorded at intervals of 1-2 $\mathrm{m}$ from a depth of $20 \mathrm{~m}$ to the ground surface.

Table 1 shows the entire measurement sequence. The recording time was one minute for every event, long enough to cover a whole construction cycle.

The equipment for measuring ground vibration included velocity sensors, connectable $50 \mathrm{~m}$ long electric cables, and a recording and storing system. A force balanced type VSE-15D velocity sensor, manufactured 
by Tokyo Dynamic Test Company, was used. The frequency range of the sensor is $0.1-70 \mathrm{~Hz}$. The measurement ranges of velocity and acceleration are \pm 10 kine $(\mathrm{cm} / \mathrm{sec})$ and \pm 2000 gal $\left(\mathrm{cm} / \mathrm{sec}^{2}\right)$ respectively. The sensitivities of the velocity and acceleration sensors were $1 \mathrm{~V} /$ kine (Volt/kine) and $5 \mathrm{mV} / \mathrm{gal}$ (micro Volt/gal), and the resolutions were $100 \mu \mathrm{kine}$ for velocity and $300 \mu \mathrm{gal}$ for acceleration. The recording, storing and data processing system was a SPC-35F system, with eight channel data logging and an amplifier system connected to a PC-98 notebook computer for storing and processing data. The resolution of the A/D interface was 16 bits and the sampling rate reached a maximum of $1000 \mathrm{~Hz}$.

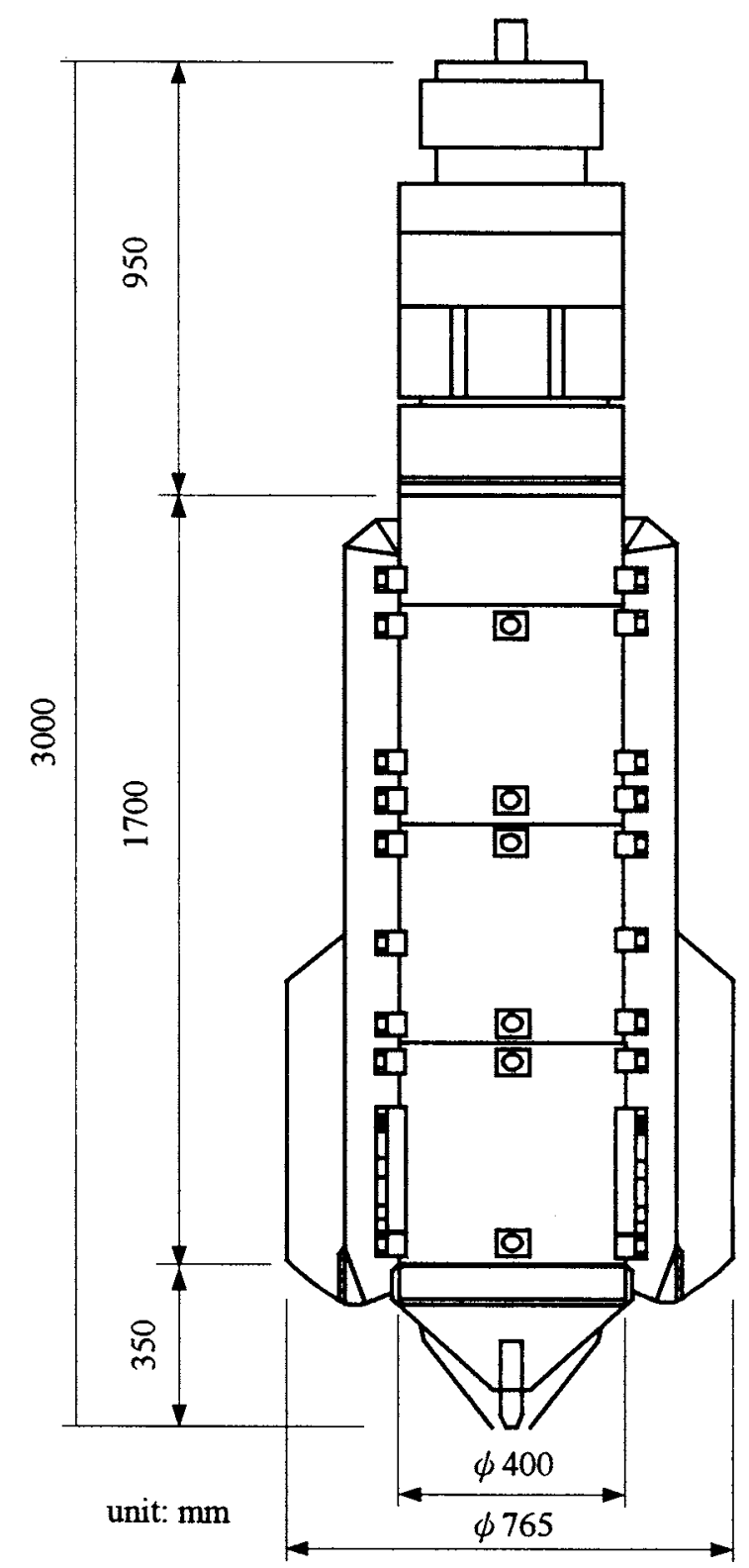

Fig. 4. The size of vibrator (German Keller S20120 type).

\section{DATA ANALYSIS}

\section{Typical Vibration Wave Form}

Figures 6 and 7 show the recorded radial and vertical velocity-time histories, respectively, at various

Table 1. Recording sequence of construction vibration for gravel pile

\begin{tabular}{cl}
\hline record number & Construction Stage \\
\hline B1 & $\begin{array}{l}\text { back ground vibration (before machine } \\
\text { is turned on) } \\
\text { back ground vibration (machine is } \\
\text { warming) }\end{array}$ \\
b3 $\begin{array}{l}\text { back ground vibration (vibrator and } \\
\text { pushing rod starting operation) }\end{array}$ \\
P011 & $\begin{array}{l}\text { initial feeding + compacting }+ \\
\text { squeezing at depth }=20 \mathrm{~m}\end{array}$ \\
P012 & start squeezing at depth $=20 \mathrm{~m}$ \\
P02 & start squeezing at depth $=18.84 \mathrm{~m}$ \\
P03 & start squeezing at depth $=16.96 \mathrm{~m}$ \\
P04 & start squeezing at depth $=15.58 \mathrm{~m}$ \\
P05 & start squeezing at depth $=13.94 \mathrm{~m}$ \\
P06 & start squeezing at depth $=12.44 \mathrm{~m}$ \\
P07 & start squeezing at depth $=10.70 \mathrm{~m}$ \\
P08 & start squeezing at depth $=9.26 \mathrm{~m}$ \\
P09 & start squeezing at depth $=7.69 \mathrm{~m}$ \\
P10 & start squeezing at depth $=6.12 \mathrm{~m}$ \\
P11 & start squeezing at depth $=4.61 \mathrm{~m}$ \\
P12 & start squeezing at depth $=2.98 \mathrm{~m}$ \\
P13 & start squeezing at depth $=1.43 \mathrm{~m}$ \\
P14 & start squeezing at depth $=0 \mathrm{~m}$
\end{tabular}

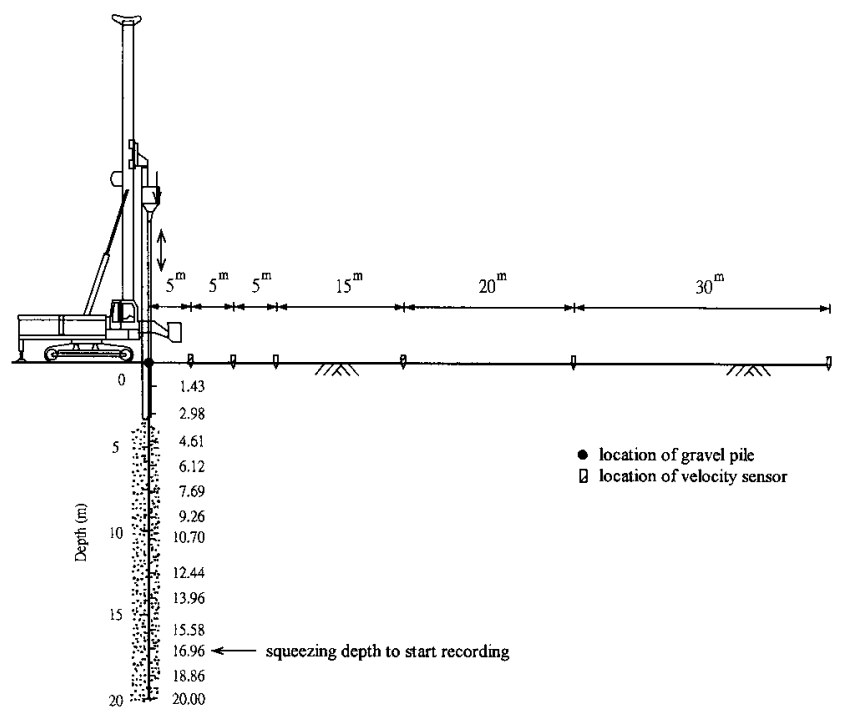

Fig. 5. The profile layout of vibration measurement. 

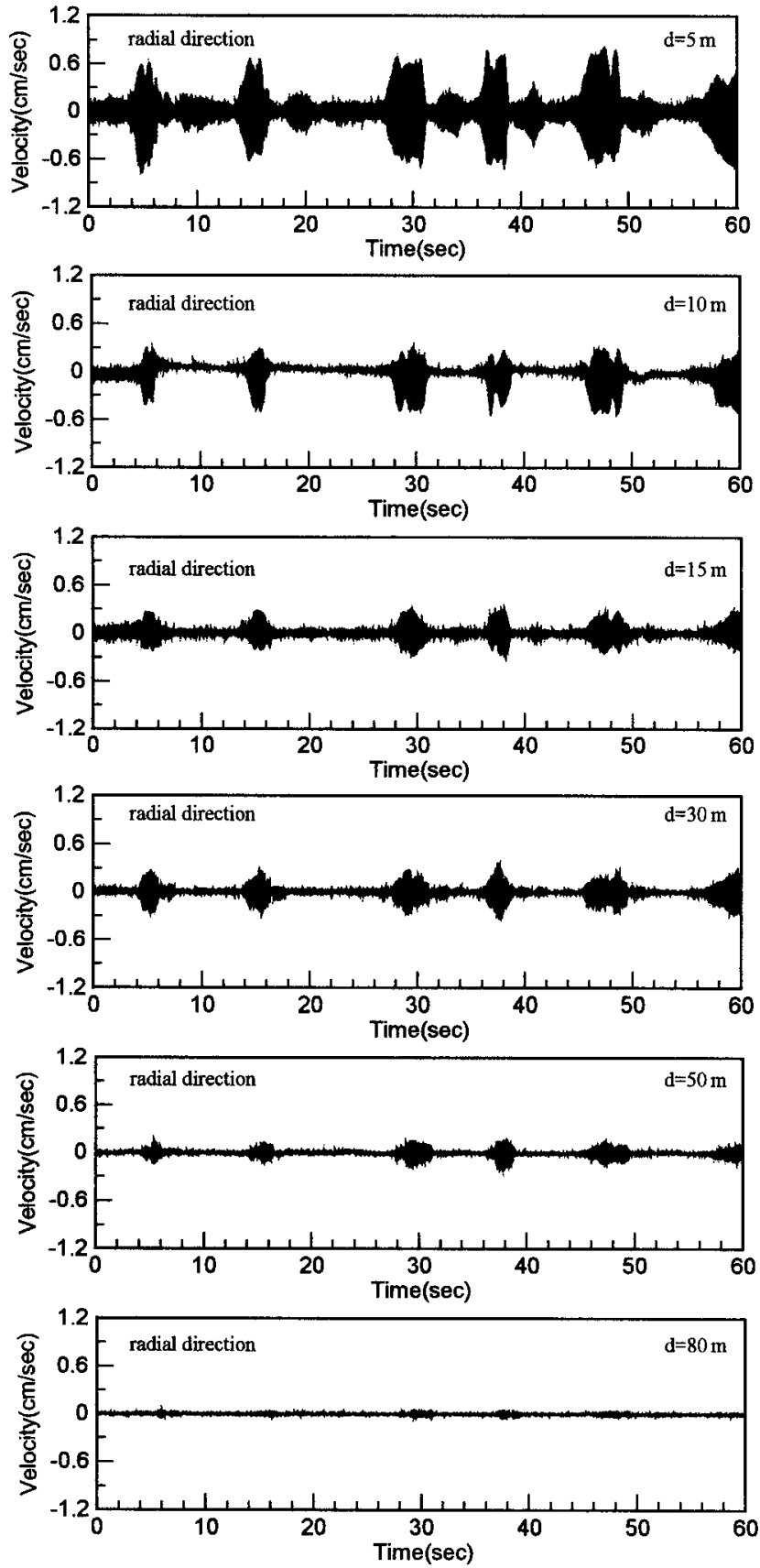

Fig. 6. The radial velocity histories at different distances when start squeezing at a depth of $2.98 \mathrm{~m}$.

distances from the vibration source, when the vibrator began squeezing at a depth of $2.98 \mathrm{~m}$. The squeezing wave form propagates from near to far and the vibration amplitude quickly attenuates with distance. Figures 8 and 9 respectively show the recorded radial and vertical velocity-time histories at $5 \mathrm{~m}$ distance from the vibration source, when the vibrator squeezed the surrounding


Fig. 7. The vertical velocity histories at different distances when start squeezing at a depth of $2.98 \mathrm{~m}$.

soils from shallow to deep. Although the periods of pulling and squeezing can be clearly identified from the velocity time history, the time histories at different squeezing depths showed no relationship, perhaps due to the uncertainties in the operational details of the vibrator and in the local soil conditions.

Figure 10 displays the paths of particle in vertical 

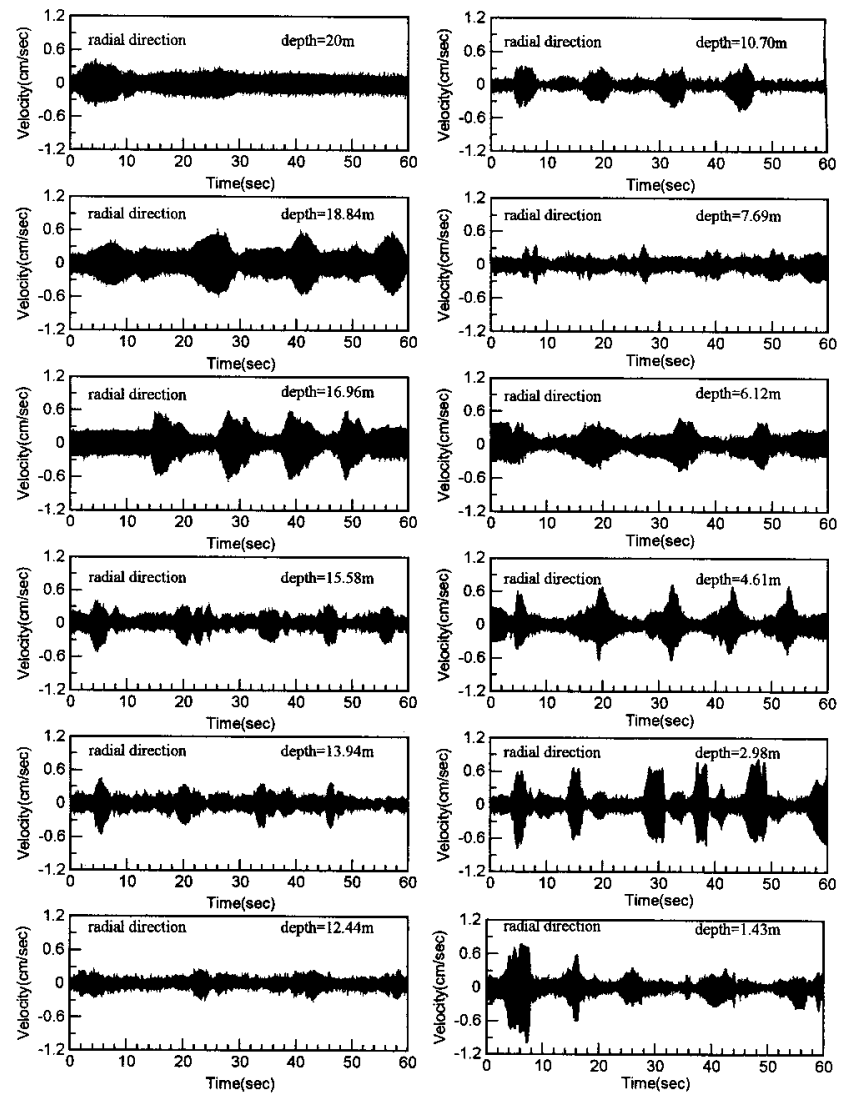

Fig. 8. The radial velocity histories at $5 \mathrm{~m}$ distance to vibration source for different squeezing depths.

and horizontal planes, over various periods of vibration records, at distances of $5 \mathrm{~m}$ and $30 \mathrm{~m}$, when the vibrator began squeezing at a depth of $2.98 \mathrm{~m}$. The paths of soil particle motions look like ellipses rotating in counterclockwise direction. The ellipse for near distance $(5 \mathrm{~m})$ is regular one, while the ellipse for far distance $(30 \mathrm{~m})$ is an oblique one. Similar observations were made at other squeezing depths.

\section{Fourier Spectrum}

Fourier transforming a velocity-time history over a complete operational cycle of pulling and squeezing yields an amplitude Fourier spectrum which represents the energy distribution of vibrational motion in a frequency domain. Figure 11 shows the Fourier amplitude spectra in radial and vertical directions at various different distances to the center of the vibration source when the squeezing depth is $18.84 \mathrm{~m}$. The peak amplitudes were observed to be centered on two narrow frequency bands, one from 30 to $35 \mathrm{~Hz}$ and the other from 60 to $70 \mathrm{~Hz}$. The corresponding peak amplitudes
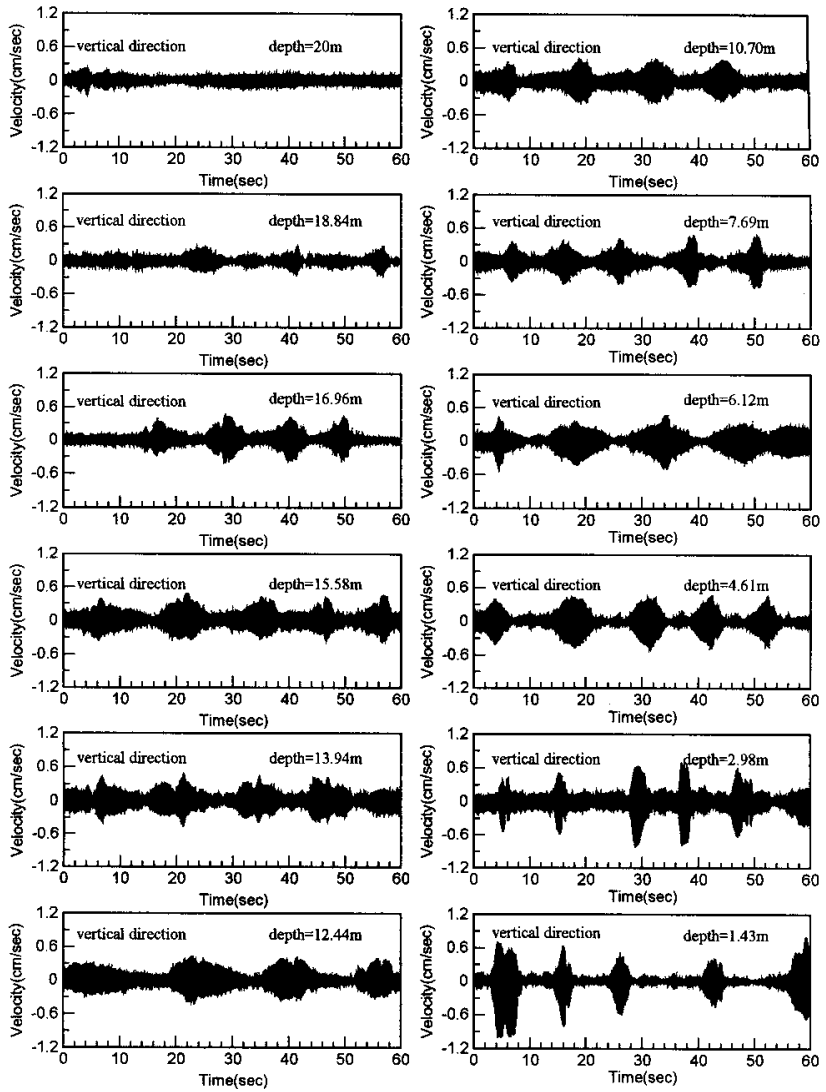

Fig. 9. The vertical velocity histories at $5 \mathrm{~m}$ distance to vibration source for different squeezing depths.

attenuate quickly with distance.

The same observation was also found for the other squeezing depths. Figures 12(a) and 12(b) are the radial and vertical Fourier amplitude spectra at $5 \mathrm{~m}$ from the vibration source for different squeezing depths. The peak amplitudes were also found to be centered on two narrow frequency bands. At a deeper squeezing depth, the two narrow bands were 30 to $35 \mathrm{~Hz}$ and 60 to $70 \mathrm{~Hz}$. The narrow band gradually shifts to lower frequencies as the squeezing depth decreases; for example, the two narrow bands are 20 to $40 \mathrm{~Hz}$ and 50 to $60 \mathrm{~Hz}$ for a squeezing depth of $2.98 \mathrm{~m}$. Many high frequency (>70 $\mathrm{Hz}$ ) signals were observed in the Fourier spectra, especially at a shallow squeezing, perhaps due to some other noise from unknown surface vibration sources.

For deep squeezing, the radial Fourier amplitude seems to exceed the vertical Fourier amplitude in the first narrow band but the amplitudes are roughly the same in the second narrow band. For shallow squeezing depths, the Fourier amplitudes in the different directions do not significantly differ for the two bands.

The operating frequency of the vibrator was $30 \mathrm{~Hz}$ 

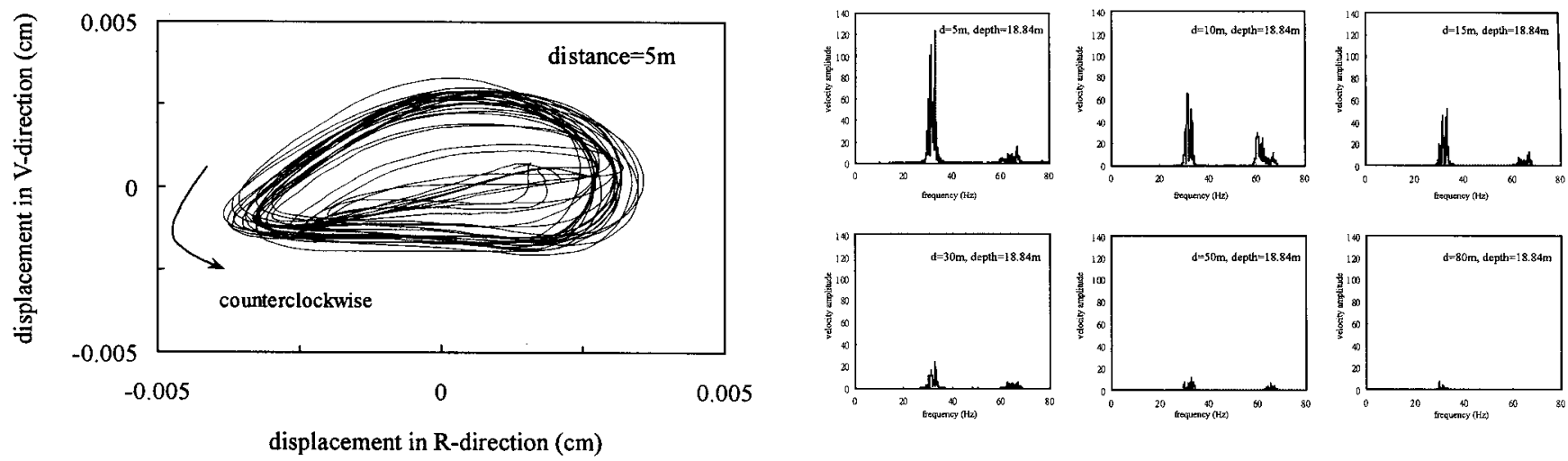

displacement in R-direction (cm)
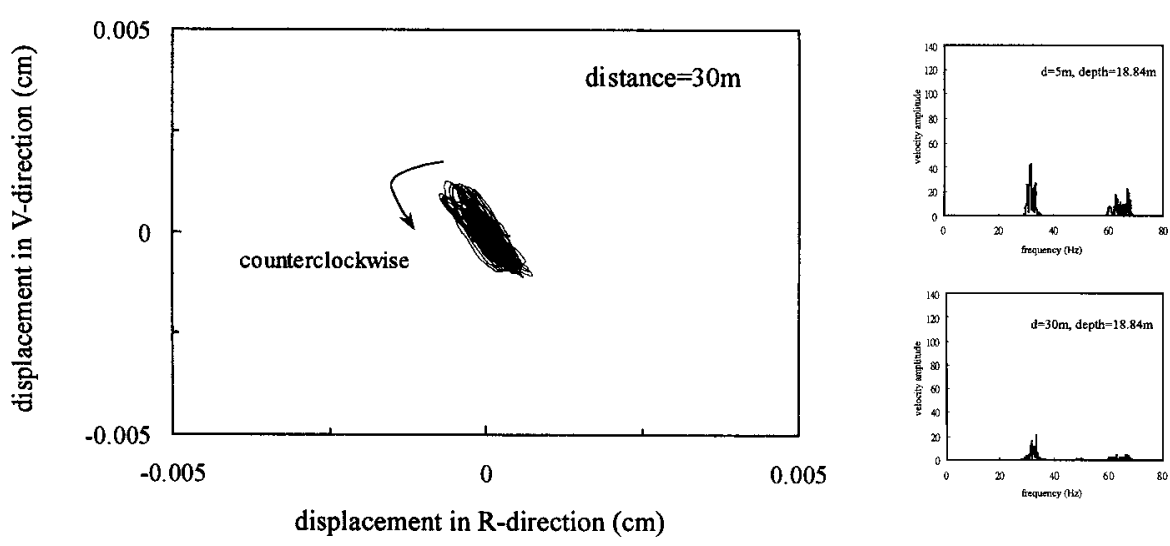

(Fourier spectra in radial direction)
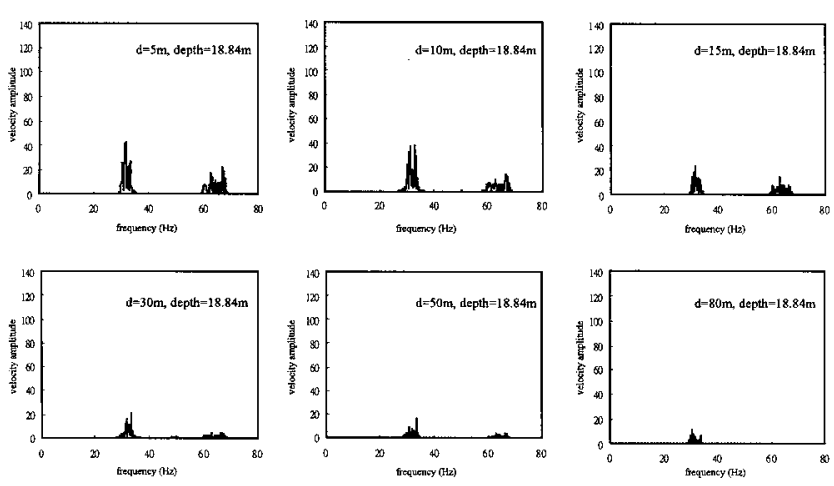

(Fourier spectra in vertical direction)

Fig. 10. The trajectories of soil particle motions.

and the rotating frequency of the electric motor was $60 \mathrm{~Hz}$. Since these two frequencies are close to the above narrow bands of ground vibration, the predominant vibration frequencies can be concluded to have been controlled by the operating frequencies of the construction machine. The spreading of the two operating frequencies to the two corresponding narrow bands may be caused by the vibrational interaction between the ground and the construction machine, or by the wave propagation effect through the non-linear viscous soil medium.

\section{Response Spectra}

Figures 13(a) and 13(b) are the normalized response spectra in radial and vertical directions, at varying distances from the center of the gravel pile. Spectral shapes were found to be rather similar regardless of squeezing depth and measuring distance. The radial and vertical spectral shapes are also quite similar. The spectral value of the long period part increases with distance. No effect of squeezing depth on the spectra can be observed.

Fig. 11. The radial and vertical Fourier spectra at different distances when start squeezing at a depth of $18.84 \mathrm{~m}$.

Most of the spectral shapes show two peak responses. The primary peak occurs for the structural period of $0.031 \mathrm{sec}$ with a normalized spectral value of 6-9. Most of the secondary peaks occur at the structural period of $0.011 \mathrm{sec}$ with a normalized spectral value of 2-4.5. When the structural period exceeds $0.031 \mathrm{sec}$, the spectral value rapidly decays with increasing period. For near distance spectra, the spectral value is less than 0.1 when the period exceeds $0.1 \mathrm{sec}$, while for far distance spectra, the spectral value is less than 0.1 until the period exceeds $0.3-0.4 \mathrm{sec}$. Therefore, for structures with fundamental vibration periods close to $0.011 \mathrm{sec}$ and $0.031 \mathrm{sec}$, possible damage to adjacent structures, due the gravel pile construction must be carefully considered.

\section{Attenuation of PGV and PGA with Distance}

Figures 14 and 15 show the attenuation relationship between both PGV and PGA with distance in radial and vertical vibration directions. The relationships 

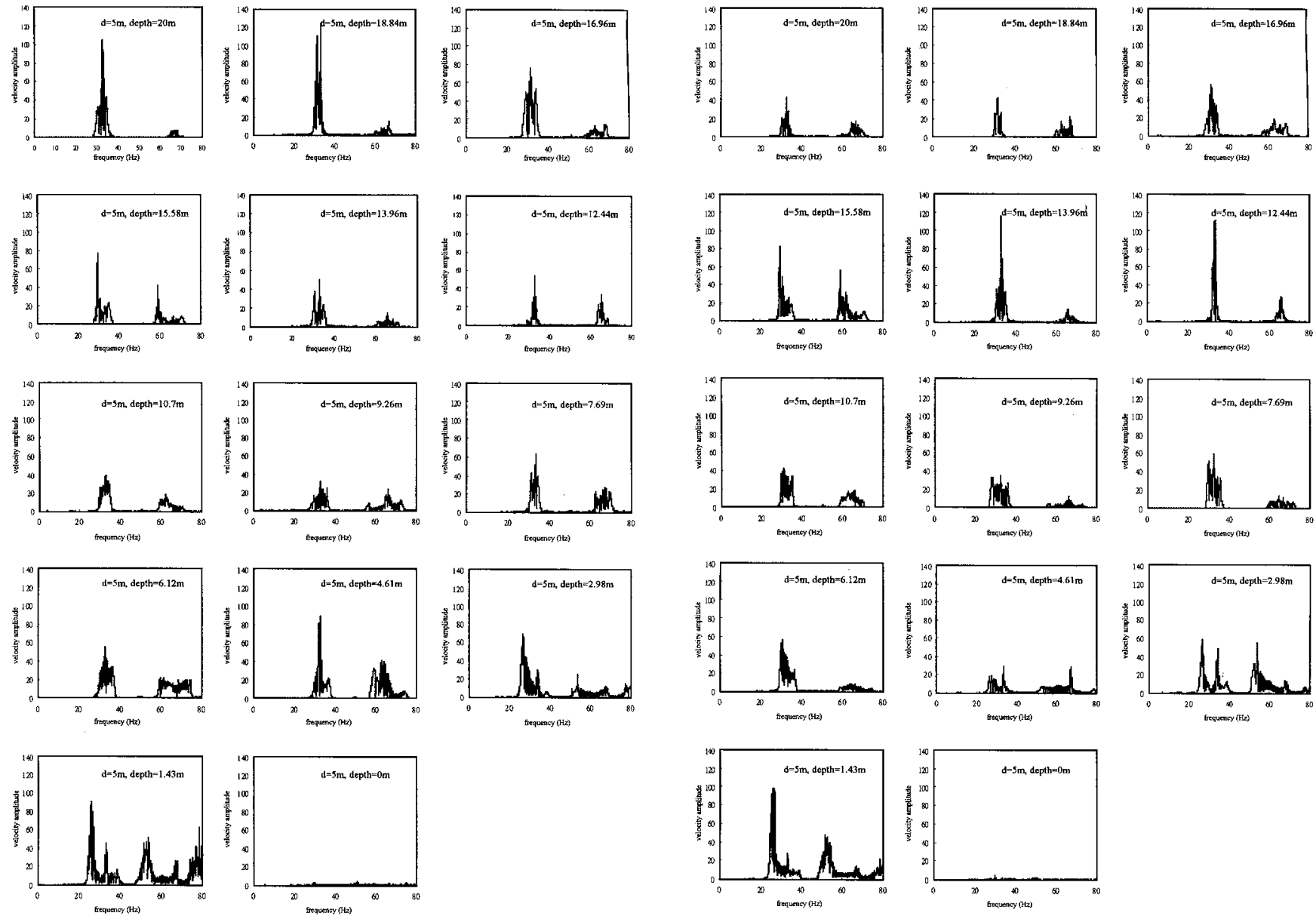

Fig. 12. (a) The radial Fourier spectra at $5 \mathrm{~m}$ distance to vibration source for different squeezing depths; (b) The vertical Fourier spectra at $5 \mathrm{~m}$ distance to vibration source for different squeezing depths.

were determined by choosing the peak amplitudes from vibration histories at the various distances during squeezing. The changes in vibration amplitudes and attenuation rates with distance are similar in both directions.

\section{SAFE CONSTRUCTION DISTANCE}

\section{Empirical Method}

In engineering practice, determining the safe construction distance to adjacent building structures is extremely important. Following an extensive review of various building vibration criteria, a vibration control criterion for local building structures has already been suggested by the authors [9]. Table 2 elucidates the criterion. Based on this criterion and the average plus one standard deviation PGV attenuation relationships shown in Fig. 14, the safe construction distance can be simply and conservatively determined. Figure 16 presents the procedure for determining the safe construction distance for a class I building structure. Table 3 shows the safe construction distances for the other structures, which were obtained in the same way. This table can serve as a preliminary guide for evaluating the effect of gravel pile construction on adjacent structures.

\section{Spectral Analysis Method}

Evaluation by the method presented here is conservative because the empirical method does not account for the vibration frequency characteristics of the building structure and the ground. A response spectral analysis method has already been presented by the authors [10] to determine more accurately the safe construction distance. Using a design response spectrum, this method can automatically account for the vibration frequency characteristics of the building structure and 

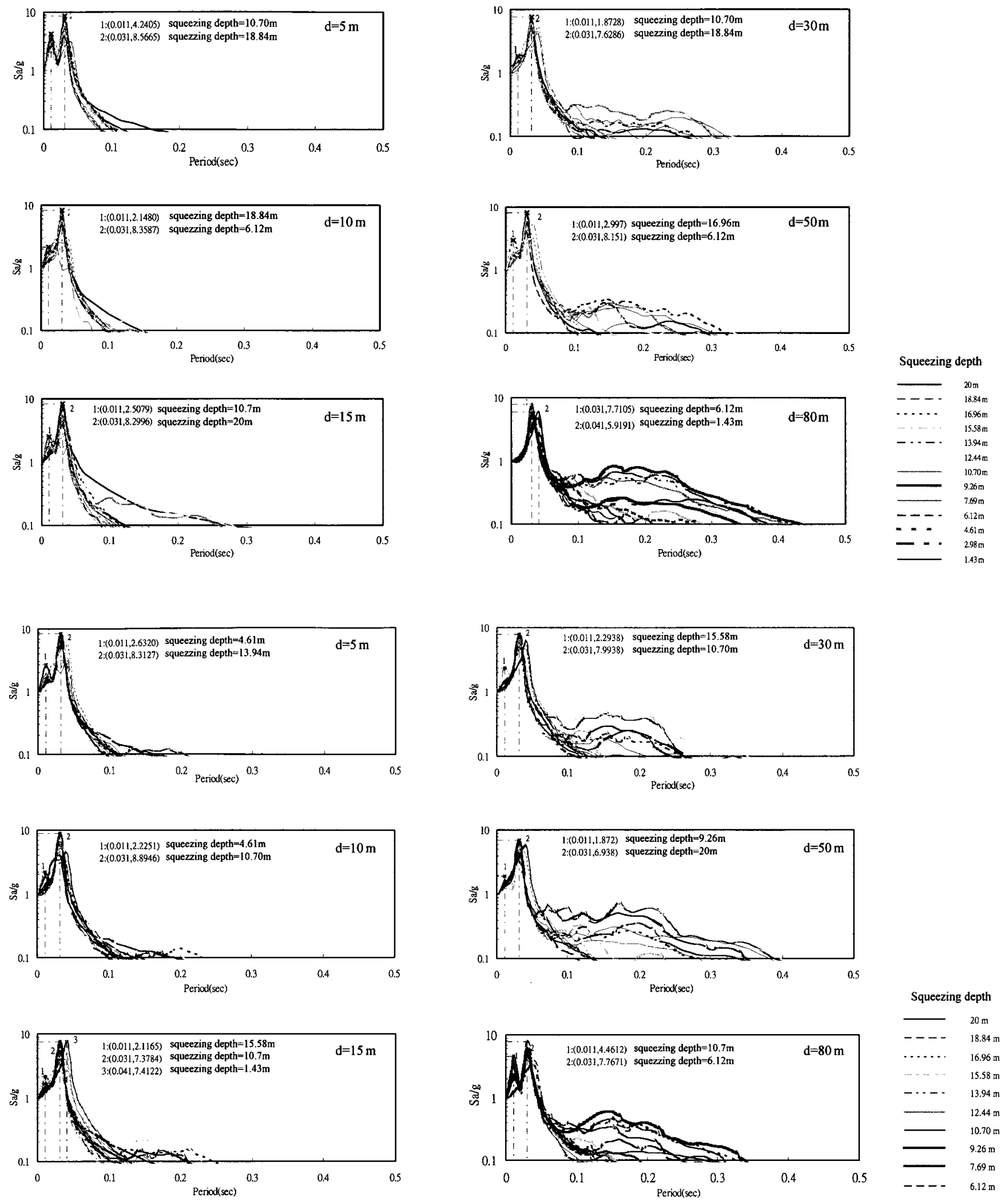

Fig. 13. (a) The radial normalized acceleration response spectra at various distances for different squeezing depths; (b) The vertical normalized acceleration response spectra at various distances for different squeezing depths. 
Table 2. The vibration criterion for various building structures [9]

\begin{tabular}{clc}
\hline & \multicolumn{1}{c}{ building type } & \multicolumn{1}{c}{ allowable value } \\
\cline { 3 - 3 } class & & $\begin{array}{c}\text { peak ground surface velocity } \\
\text { PGV (mm/sec) }\end{array}$ \\
\hline I & ruins, historic buildings, old temples and buildings with high precision equipments. & 4 \\
II & masonary or reinforced masonary buildings & 7 \\
III & stiff modern reinforced concrete or structural steel buildings & 25 \\
\hline
\end{tabular}

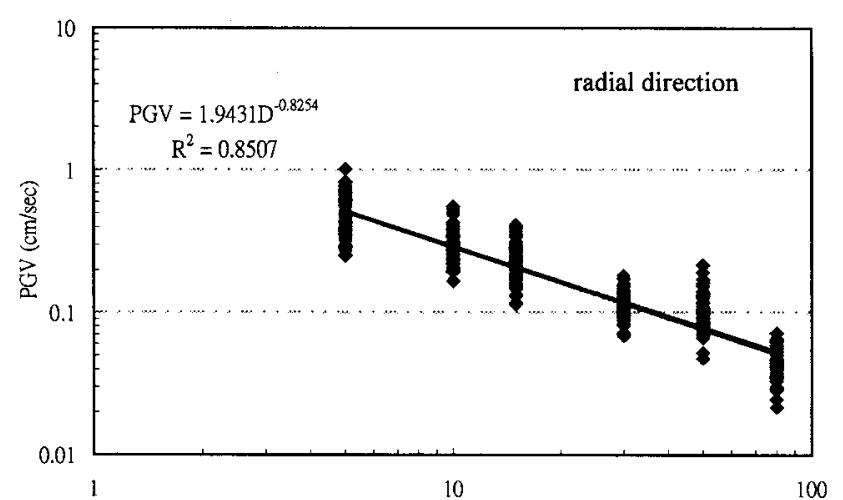

distance to vibration source, D (m)

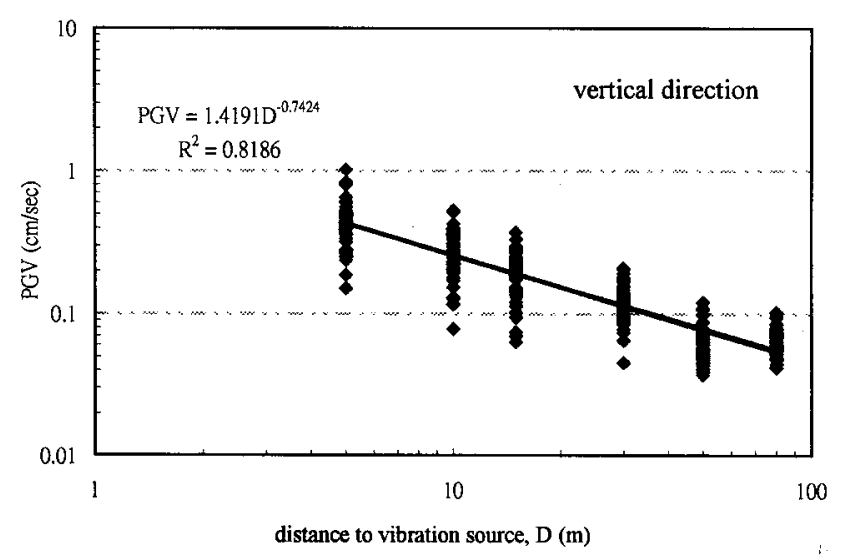

Fig. 14. The attenuation relations of PGV with distance in radial and vertical directions.

the ground. Deriving the design response spectra of the vibration records due to gravel pile construction is the most important part of applying this methods. Figure 17 is the statistical result of the response spectra of all vibration records. The suggested design spectra and their formula are also shown in the figure. Based on the design spectra and the PGA attenuation relationships shown in Fig. 15, a response spectral analysis method can be used to evaluate the safe construction distance.


Fig. 15. The attenuation relations of PGA with distance in radial and vertical directions.

\section{CONCLUSION}

Based on the study, the following conclusions can be drawn.

1) The two predominant frequency bands of the ground vibration due to gravel pile construction are excited by the two operating frequencies of the construction machine.

2) The ground vibration characteristics are similar in radial and vertical directions.

3) The construction vibration of the gravel pile is more harmful to structures with vibration peri- 
Table 3. The safe construction distances in two directions for various building structures

\begin{tabular}{clrr}
\hline class & \multicolumn{1}{c}{ building type } & \multicolumn{2}{c}{$\begin{array}{c}\text { safe construction distance } *(\mathrm{~m}) \\
\text { vertical direction }\end{array}$} \\
& & 9.0 & 10.0 \\
radial direction
\end{tabular}

* The distance is determined by the corresponding distance of the average plus one standard deviation PGV attenuation relation to the allowable PGV value. The distances are all rounded off.
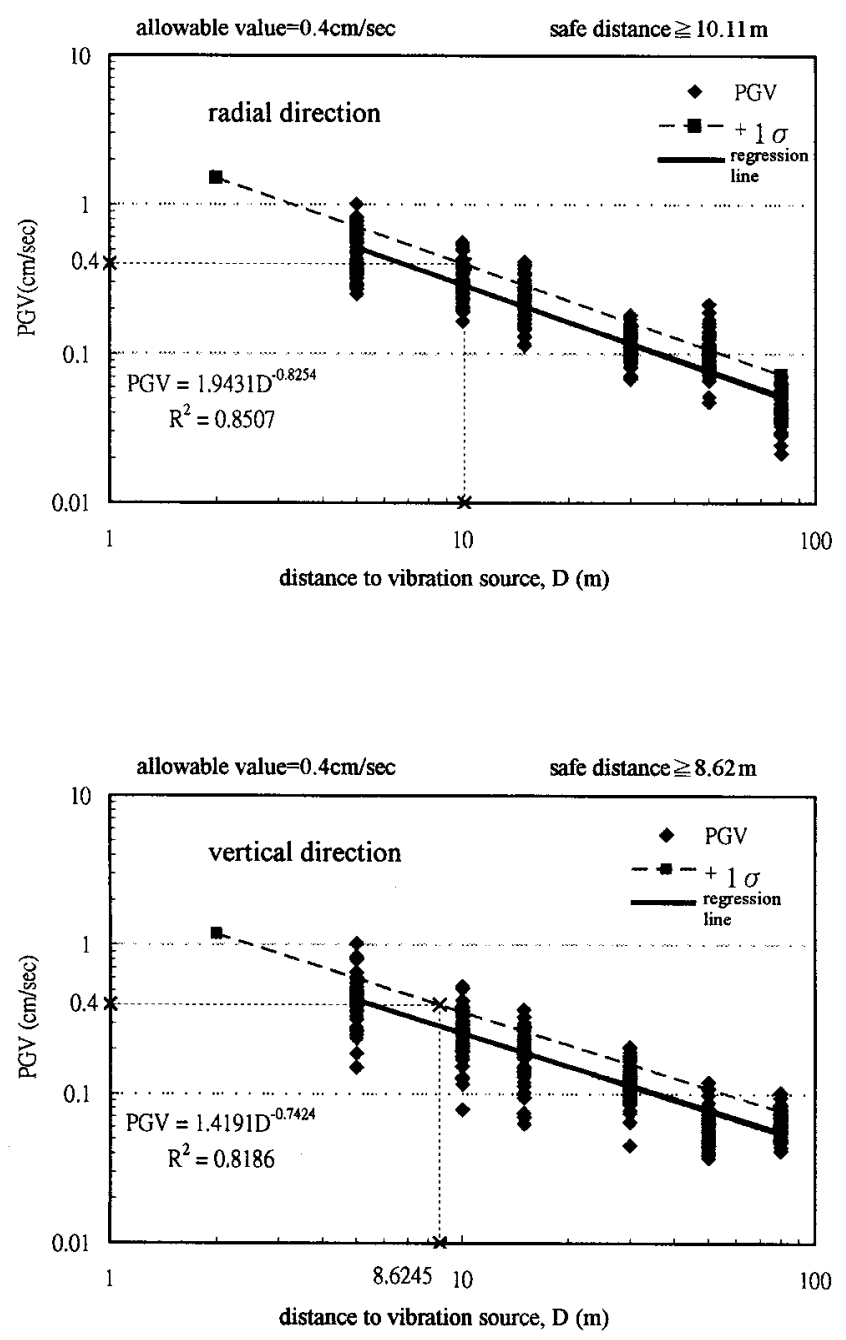

Fig. 16. The determination of safe construction distance for class I building by an allowable PGV value.

ods close to $0.011 \mathrm{sec}$ and $0.031 \mathrm{sec}$.

4) An empirical method and a spectral analysis method were proposed for application by engineers to evaluate the effect of gravel pile construction on adjacent structures.


Fig. 17. The suggested design spectra for near distance $(<30 \mathrm{~m})$ and for distance $(\geq 30 \mathrm{~m})$ 


\section{ACKNOWLEDGEMENT}

This research was sponsored by RSEA Company. The author would like to extend his sincere gratitude to RSEA for the support.

\section{RENFERENCES}

1. Attewell, P.D., and Farmer, I.W., "Attenuation of Ground Vibration from Pile Driving," Ground Engineering, Vol. 6, No. 4, pp. 26-29 (1971).

2. Wiss, J.F., "Construction Vibration : State-of-The-Art," Journal of Geotechnical Engineering, Division, ASCE, Vol. 107, No. GT2, pp. 167-181 (1981).

3. Theissen, J.R., and Wood, W.C., "Vibration in Structures Adjacent to Pile Driving," Dames and Moore Engineering Bulletin, No. 60, pp. 4-21 (1982).

4. Woods, R.D., and Larry, P.J., "Energy-Attenuation Relationships from Construction Vibrations," Proceedings of Vibration Problems in Geotechnical Engineering , ASCE Convention, Detroit, Michigan, pp. 229-246 (1985).

5. Skipp, B.O. and Barkley, J.S., "Ground Vibration from Impact," Proceedings of Ninth International Conference on Soil Mechanics and Foundation Engineering, Vol. 2, pp. 397-401 (1977).

6. Mayne, P.W., "Ground Vibrations during Dynamic Compaction," Proceedings of Vibration Problems in Geotechnical Engineering , ASCE Convention, Detroit, Michigan, pp. 247-265 (1985).

7. Clough, G.W. and Chameau, J.L., "Measured Effects of Vibratory Sheet-pile Driving," Journal of Geotechnical Engineering Division, ASCE, Vol. 106, No. GT10, pp.
1081-1099 (1980).

8. Sarsby, R.W., "Ground Vibrations from Sheet-Piling Operations," International Symposium on Environmental Geotechnology, pp. 655-666 (1983).

9. Hwang, J. H., "Effect of Ground Vibration to Adjacent Structures Due to Pile Driving (I)," RSEA Research Report, Taipei (2000).

10. Hwang, J. H., "Effect of Ground Vibration to Adjacent Structures Due to Pile Driving (II)," RSEA Research Report, Taipei (2001).

\section{碟石椿施工引致之地盤振動}

$$
\text { 黄 俊鴻 杜東 岳 }
$$

國立中央大學土木工程學系

$$
\text { 摘 要 }
$$

本文在台灣中部某一代表性之水力回填工業區 場址, 成功地進行礫石椿施工引致之地盤振動量測, 並以振動波形, 富氏譜與結構反應譜探討此種施工之 地盤振動特性。同時也整理統計出最大地表速度與加 速度隨距離衰減之關係。結合地動量衰減關係與建築 物振動管制準則, 本文建議了一種簡單決定碩石椿施 工對建筑物影響安全距離之經驗評估法。本文也建議 了此種施工振動之設計反應譜, 可供工程師使用結構 動力分析中常用之反應譜分析法, 以更準確地評估砅 石椿施工之安全距離。 